\title{
Efektifitas Terapi SEFT (Spiritual Emotional Freedom Technique) Terhadap Penurunan Agresifitas Remaja Warga Binaan Lembaga Pembinaan Khusus Anak (LKPA) Kelas I Blitar
}

\author{
Arman Marwing \\ marwingarman@gmail.com
}

\author{
Jurusan Tasawuf dan Psikoterapi IAIN Tulungagung, Indonesia
}

\begin{abstract}
This study aimed to determine the impact of Spiritual Emotional Freedom Technique (SEFT) therapy on reducing the level of aggressiveness in adolescent-assisted residents in specialized child development institutions. The subjects of the study were sixteen adolescents fostered by class 1 special development institutions for children in Blitar. This research is an experimental quantitative research with one group pretest-posttest experimental design. Data collection method conducted using Buss \& Perry's aggressiveness scale to measure the changes that occur after the award. The two paired test results obtained asymp values. Sig (2-tailed) of 0,030 . Because the significance value of 0,030 $<0,05$, it can be concluded that there is a significant difference in filling the Buss \& Perry aggressiveness scale questionnaire on filling before and after treatment. The test results also showed the correlation between the two variables is equal to 0,168 . This shows that the correlation between before and after the given commitment is significantly related or the existence of a weak positive correlation. Broadly speaking, it can be concluded that Spiritual Emotional Freedom Technique (SEFT) therapy has an effect on the reduction in the aggressiveness of Adolescents fostered by the Class I Special Child Development Institute (LPKA) of Blitar.
\end{abstract}

Keywords: adolescent; aggressiveness;LPKA;SEFT.

\begin{abstract}
Abstrak
Penelitian ini bertujuan untuk mengetahui dampak terapi Spiritual Emotional Freedom Technique (SEFT) terhadap penurunan level agresifitas pada remaja warga binaan di lembaga pembinaan khusus anak. Subjek penelitian adalah enam belas remaja warga binaan lembaga pembinaan Khusus anak kelas I Blitar. Penelitian ini merupakan penelitian kuantitatif eksperimen dengan rancangan eksperimen one group pretest-posttest. Metode pengumpulan data dilakukan dengan menggunakan skala agresifitas Buss \& Perry untuk mengukur perubahan yang terjadi setelah pemberian tritmen. Hasil uji beda dua berpasangan didapatkan nilai asymp. Sig (2-tailed) sebesar 0, 030. Karena nilai signifikansi $0,030<0,05$, maka dapat disimpulkan bahwa ada perbedaan yang signifikan pada pengisian kuesioner agresifitas skala agresifitas Buss \& Perry pada pengisian sebelum dan setelah pemberian perlakuan. Hasil uji juga menunjukkan korelasi antara dua variabel adalah sebesar 0, 168 . Hal ini menunjukkan bahwa korelasi antara sebelum dan sesudah diberikan tritmen berhubungan secara nyata atau adanya korelasi positif yang lemah. Secara garis besar dapat disimpulkan bahwa terapi Spiritual Emotional Freedom Technique (SEFT ) berpengaruh terhadap penurunan agresifitas Remaja warga binaan Lembaga Pembinaan Khusus Anak (LPKA) Kelas I Blitar.
\end{abstract}

Kata kunci: agresifitas; LPKA; remaja;SEFT.

Psikoislamika: Jurnal Psikologi dan Psikologi Islam (JPPI) Volume 16. Nomor 1. Tahun 2019. Copyright (C) 2019. Pusat Penelitian dan Layanan Psikologi. 


\section{PENDAHULUAN}

Kasus perilaku agresif yang mengarah kepada tindakan kriminalitas dengan pelaku anak anak dan remaja semakin massif terjadi. Penjelasan Asosiasi perilaku agresif remaja menurut Replein (dalam Monks et al., 2006) berasal dari ketidakmampuan remaja dalam memenuhi tugas perkembangan dengan baik sehingga terjadi krisis (identity vs confussion identity) yang ditunjukkan dalam bentuk kepekaan dan labilitas tinggi, penuh gejolak, kestabilan emosi, sehingga kerentanan bereaksi spontan ketika emosi tersulut.

Data KPAI menunjukkan adanya kenaikan kasus kriminalitas anak (remaja) dari 67 kasus pada tahun 2014, meningkat menjadi 79 kasus pada tahun 2015 (Bisnis, 2016). Dalam bentuknya, Pelbagai jenis pelanggaran yang dapat menjadikan anakanak berhadapan dengan hukum tersebut menurut pasal 1 huruf 2 UU No. 3 tahun 1997 tentang pengadilan anak dibagi menjadi dua jenis yakni status offences dan criminal offences. Status Offences merupakan tindakan yang tidak dikategorikan kriminal jika dilakukan oleh orang dewas. Dengan kata lain, tindakan tersebut dikatakan sebagai pelanggaran hukum hanya karena status pelaku yang melakukannya berada di bawah umur yang telah ditetapkan. Contoh yang paling jelas misalnya meminum-minuman keras, membolos dari sekolah, kabur dari rumah dan melanggar norma kesusilaan. Sementara criminal offences merupakan tidakan melawan hukum yang dapat diganjar dengan hukuman oleh negara atau aparat hukum. Contoh criminal offences yaitu tawuran, pencurian, penjambretan, kekerasan seksual , penganiayaan, dan pembunuhan (KPAI, 2019). Masing- masing dari jenis tesebut memiliki konsekuensi hukum yang berbeda , namun tidak sedikit kasus-kasus tersebut berakhir dengan putusan pengadilan.

Banyaknya kasus perkara anak-anak yang berkonflik dengan hukum yang ditengarai karena krisis identitas (Monks, dkk., 2006), keterkaitan dengan temperamen, ketidakmampuan mengelola tekanan jiwa, konflik batin, frustasi sehingga mengarah pada perilaku agresif impulsif,spontan dan primitif (Kartono, 2014) menjadi pertimbangan diperlukannya pemberian perlakuan khusus bagi mereka ketika berhadapan dengan hukum. Salah satunya perlakuan khusus yaitu penempatan anak bermasalah dengan hukum pada lembaga pembinaan khusus anak sebagaimana yang diatur secara khusus melalui Undang-Undang No.3 tahun 1997 yang kemudian diubah menjadi Undang- undang no 11 tahun 2012 tentang sistem peradilan Anak. Dalam aturan tersebut mengatur bahwa anak-anak yakni berusia di bawah 18 tahun dan menjalani masa pidana ditempatkan ke dalam LPKA . (Hukum Online, 2019).

Selama ini penahanan dalam penjara pada anak memberikan efek buruk teutama kekerasan (Kompas, 2010), rendah diri,terserapnya norma-norma eskploitatif dari budaya penjara, serta stigmatisasi penahanan yang menghasilkan isolasi sosial dari komunitas (Haney, C, 2003). Oleh karena itu, dengan penempatan anak ke dalam LPKA memungkinkan tercegahnya dampak buruk tersebut serta terpenuhinya hak-hak anak antara lain mengenai pertumbuhan dan perkembangan holistik yang mencakup aspek fisik, mental, maupun sosial anak (Redaksi Sinar Grafika, 2002).

Satu diantara lembaga tersebut adalah lembaga pembinaan khusus anak (LPKA) kelas I Blitar. Di lembaga tersebut, anak berkisar 11-18 tahun didik 
agar menjadi pribadi yang tangguh, mandiri serta menumbuhkan kesadaran diri terhadap peraturan dan kedisiplinan sehingga selanjutnya lebih peduli terhadap lingkungan, menghormati orang lain dan berubah menjadi pribadi yang lebih baik (wawancara dengan Kepala LPKA, 2017)

Ironisnya, meskipun program sistematis dan intensif, agresifitas dan perilaku agresif masih sering ditemukan. Beberapa kasus perilaku agresif diantaranya kasus perkelahian, pemukulan serta kekerasan bersifat intimidatif berupa pemalakan terhadap uang, makanan, rokok dan kepemilikan berharga lainnya. Bentuk agresifitas lainnya juga dalam bentuk perusakan terhadap fasilitas-fasilitas seperti WC /Toilet, kamar mandi, kamar serta beberapa fasilitas untuk hiburan (Wawancara dengan NN, 2017). Kasuskasus perilaku agresif tersebut seringkali terjadi baik yang diketahui dan dicatat petugas, terlebih lagi yang tidak diketahui petugas.

Kcenderungan agresifitas pada diri remaja warga binaan yang diwujudkan dalam pelbagai perilaku agresif di kalangan residen LPKA Anak Kelas I Blitar membutuhkan penanganan yang serius dan tidak konvensional. Jika kondisi ini dibiarkan, perilaku agresif warga binaan selain menganggu pelaksanaan program pembinaan itu sendiri juga akan berdampak buruk pada penyesuaian diri mereka saat kembali di tengah-tengah masyarakat

Dapat dicermati bentuk pembinaan dan rehabilitasi di LPKA belum efektif dalam mengurangi perilaku agresif di kalangan anak (anak dan remaja) di LPKA. Untuk mengatasi hal tersebut terdapat beberapa metode yang dapat dilakukan dalam menurunkan dan mengendalikan perilaku agresif (agresifitas) diantaranya terapi Spiritual Emotional Freedom Technique (SEFT). SEFT merupakan penggabungan terapi psikologi dengan nilai-nilai spiritual (Tasawuf). SEFT dapat diterapkan sebagai tritmen agresifitas kepada warga binaan LPKA karena mampu menstabilkan pikiran dan emosi melalui totok ringan (tapping) pada titik meridian tubuh serta dikombinasikan dengan doa sehingga subjek memiliki kontrol diri serta konsep diri yang positif. Adanya pengendalian diri yang baik tersebut dapat mengurangi perilaku agresif residen LPKA (Zainuddin, 2010).

Landasan efektifitas penelitian terapi di atas dalam mengatasi masalah fisik dan emosi sangat banyak ditemukan namun penelitian spesifik tentang efektifitas terapi SEFT dalam menurunkan perilaku agresif sangat jarang ditemukan. Salah satu penelitian yang memiliki keterkaitan yakni penelitian yang dilakukan Sakdullah (2013) mengenai terapi SEFT terhadap penurunan permasalahan agresifitas remaja. Dalam penelitian tersebut, sampel merupakan siswa pada Institusi pendidikan berbasis Islam yang memiliki tingkat agresifitas yang tinggi dan tinggi. Berdasarkan uji analisis uji- $t$ dependent menemukan bahwa terdapat perubahan signifikan antara hasil pre-test dan posttest, yang menunjukkan adanya penurunan tingkat agresifitas akibat adanya perlakuan berupa terapi SEFT.

Berdasarkan keefektifan terapi SEFT dalam menurunkan agresifitas pada penelitian tersebut, penelitian ini mencoba untuk menguji keefektifan intervensi yang sama, jenis penelitian kuantitatif eksperimen dengan desain one group pretest-post test, namun dengan karakteristik populasi dan lingkungan yang berbeda. Jika Sakdullah menggunakan SEFT dalam lingkup sekolah yakni MA darul Ulum 
Ngaliyan- Semarang yang secara general adalah representasi masyarakat umum, maka penelitian ini menggunakan jenis terapi dan desain penelitian yang sama untuk sampel dengan kecenderungan perilaku agresif di lingkup tempat khusus yakni lembaga pemasyarakata khusus anak (LPKA) anak. Pemilihan LPKA menjadi tempat penelitian karena subjek di lembaga tersebut merupakan tempat spesifik bagi subjek dengan permasalahan yang berkaitan dengan hukum serta kemudahan dalam mengontrol perkembangan subjek penelitian dengan bantuan pamong atau pembina.

Berdasarkan pada fenomenafenomen perilaku agresif yang semakin marak khususnya yang terjadi pada warga binaan lembaga pembinaan khusus anak serta efektifitas terapi SEFT dalam menurunkan perilaku emosional seperti perilaku agresi, maka peneliti tertarik melakukan penelitian eksperimental yang berjudul “ Efektivitas Terapi SEFT (Spiritual Emotional Freedom Technique)) Terhadap Penurunan Agresifitas Remaja Warga Binaan Lembaga Pembinaan Khusus Anak (LPKA) Kelas I Blitar". Tujuan yang ingin dicapai dari penelitian ini menguji pengaruh terapi SEFT dalam menurunkan agresifitas pada remaja warga binaan Lembaga Pembinaan Khusus Anak (LPKA) Kelas I Blitar.

Manfaat teoritis dari penelitian ini diharapkan dapat memperkaya wawasan teoritik dalam bidang psikoterapi tasawuf khususnya kajian mengenai landasan teoritik gangguan psikologis berdasarkan tinjauan Tasawuf serta analisis modelmodel integratif terapan tasawuf dan metode psikoterapi barat khusunya SEFT dalam penanganan masalah psikologis remaja. Sedangkan manfaat praktis jika penelitian ini terbukti, maka akan bermanfaat bagi residen remaja Lembaga Pembinaan Khusus Anak (LPKA) Kelas I
Blitar bahwa dengan terapi SEFT agresifivitas mereka akan menurun. Selain itu terapi SEFT dapat dijadikan sebagai altenatif metode yang mudah dan murah, dan dapat dipelajari serta digunakan oleh terapis di LPKA baik dari psikolog, pekerja sosial atau petugas LPKA sendiri untuk mengurangi perilaku agresif residen remaja Lembaga Pembinaan Khusus Anak (LPKA).

Jika mengacu pada teori-teori mengenai agresifitas maka dapat dikatakan bahwa agresifitas remaja adalah perilaku dengan tujuan menyakiti dalam berbagai bentuk manifestasinya yang dilakukan oleh individu berusia 13 hingga 18 tahun (Hurlock, 2003). Dari jeni motif, agresi dapat dibedakan menjadi agresi antisosial dan prososial. Agresi antisosial merupakan tindakan kriminal tak beralasan yang melukai orang lain atau yang melanggar norma sosial, seperti penyerangan dengan kekerasan, pembunuhan, dan pemukulan oleh sekelompok orang. Agresi prososial menekankan pada norma sosial yang mengatur berbagai tindakan agresif, misalnya tindakan yang sesuai hukum, disiplin yang diterapkan oleh orang tua, atau kepatuhan terhadap perintah komandan pada waktu perang (Sears, 2001).

Kedua pengertian di atas mencoba mengklasifikasi agresi berdasarkan motif nya sementara Baron \& Byrne (2005) mencoba membedakan bentuk agresifitas menjadi dua yaitu agresifitas fisik dan agresi verbal. Agresi fisik meliputi tindakan melukai atau menyakiti badan sementara agresifitas verbal yaitu agresi yang dilakukan dengan mengucapkan kata kata kotor atau kasar. Adapun jenis angresifitas yang ingin diturunkan melalui terapi SEFT dalam penelitian ini adalah empat bentuk perilaku agresi agresif Buss dan Perry (1992) yaitu a.) Agresi verbal ,b.) Agresi non verbal, c.) Agresi kemarahan, dan d.) Agresi permusuhan. Pembagian perilaku agresi agresif Buss dan Perry (1992) merupakan 
upaya penggabungan antrara motif dan bentuk perilaku dari para ahli sebelumnya dan menjadi fokus sasaran perilaku yang ingin dirubah.

Agar suatu intervensi dapat efektif, maka dalam pemberian intervensi harus menggunakan metode yang dapat diterima dan sesuai dengan klien (Wallin, dan Durr, 2002). Perilaku agresif, seperti gangguan emosi lainnya seperti stres dan depresi selain disebabkan karena ketidakseimbangan kimiawi, juga dipengaruhi oleh adanya gangguan energi tubuh yang kasat mata. Sistem energi tubuh yang terganggu akibat terhambatnya aliran energi tersebut bisa dirasakan dalam wujud emosi dan sakit fisik pada bagin tubuh tertentu. Oleh karena itu untuk menyelesaikan masalah agresifitas, Terapi Spiritual Emotional Freedom Technique (SEFT) merupakan terapi yang tepat diberikian karena terapi ini secara langsung berurusan dengan " gangguan sistem energi tubuh " dengan memberikan intervensi terhadap titik kunci dari energi tubuh yang berjumlah 18 titik pada tubuh manusia atau atau " the major energy meridians" sehingga gangguan sistem energi tubuh dapat diperbaiki, aliran energi menjadi lancar, dan luapan emosi negatif khususnya yang mendorong perilaku agresif akan hilang dengan sendirinya atau akan mendapatkan inspirasi tentang penyelesaian masalah-masalah yang dihadapi (Zainuddin, 2010).

Pada praktinya, penyelarasan kembali energi tubuh dalam kasus agresifitas dilakukan meliputi tiga tahapan yakni the set -up (menetralisir energi negatif yang ada di tubuh), the tune in (mengarahkan pikiran pada tempat rasa sakit) dan the tapping (mengetuk ringan dengan dua ujung jari pada titik titik tertentu di tubuh manusia) (Zainuddin, 2010). Dengan melaksanakan prosedur di atas agresifitas sebagai salah satu bentuk dari emosi negatif, yang disebabkan oleh terdapatnya gangguan sistem energi tubuh dapat diatasi dengan tapping, dan juga penggunaan doa dan aspek spiritual yang sangat kental dalam terapi SEFT ini akan memberikan efek yang melipatgandakan penyembuhan atau pengatasan masalah emosi termasuk agresifitas .

Berdasarkan dari penjelasan di atas, hipotesis dalam penelitian ini yaitu Ho : Terapi Spiritual Emotional Freedom Technique (SEFT) tidak berpengaruh terhadap penurunan agresifitas Remaja warga binaan Lembaga Pembinaan Khusus Anak (LPKA) Kelas I Blitar dan Ha: Terapi Spiritual Emotional Freedom Technique (SEFT) berpengaruh terhadap penurunan agresifitas Remaja warga binaan Lembaga Pembinaan Khusus Anak (LPKA) Kelas I Blitar.

\section{METODE}

Jenis penelitian yang digunakan dalam penelitian ini adalah penelitian kuantitatif eksperimen dengan rancangan eksperimen one group pretest-posttest design. Desain penelitian mengunakan dua kelompok variabel, yaitu agresifitas sebelum diberi terapi SEFT dan agresifitas setelah diberi terapi SEFT. Penelitian dilakukan di LPKA Kelas I Blitar dengan populasi berjumlah 40 residen remaja yang sedang menjalani pembinaan secara rutin dan intensif. Pengambilan sampel yang digunakan adalah purposive sampling dengan mengacu pada kriteria sebagai berikut : (1) warga binaan yang memiliki catatan kasus kekerasan periodik selama proses pembinaan di LPKA seperti agresi verbal, agresi non verbal, agresi kemarahan, dan agresi permusuhan. Selain itu sampel juga harus memenihi kriteria umum diantaranya: (2) Umur antara 13- 18 Tahun ; (3) Jenis Kelamin Laki-laki; (34Tercatat sebagai warga 
binaan di LPKA Kelas I Blitar (5) Bersedia menjadi subjek penelitian. Berdasarkan kriteria tersebut didapatkan sampel sebanyak 16 residen remaja yang memenuhi kriteria tersebut.

Sampel diukur tingkat agresifitasnya dengan menggunakan kuesioner skala agresifitas Buss \& Perry (2002) yang terdiri dari 29 item dengan empat aspek, yakni aspek anger atau kemarahan (7 item yakni item 3, 15, 16, $11,22,7,29)$ seperti pernyataan "Saya mudah marah, tetapi mudah pula melupakan kemarahan saya" ; agresi verbal (5 item yakni 2, 18, 6, 10, 14) seperti pernyataan "Bila saya tidak setuju dengan teman saya, saya akan langsung membantahnya" ; Agresi Fisik (10 aitem yakni aitem 1, 5, 9, 24, 19, 13, 21, 17, 26, 28) seperti pernyataan "Terkadang saya begitu ingin memukul teman saya" dan permusuhan (8 item yakni aitem $4,8,12$, 20, 23, 27, dan 25) seperti pernyataan "Saya tahu, teman-teman sering membicarakan kejelekan saya tanpa sepengetahuan saya". Peneliti juga melakukan uji validitas dan reliabilitas instrumen sebelum digunakan untuk penelitian dengan hasil 28 item valid dan 1 item tidak valid serta nilai Cronbach's Alpha sebesar 0,90 yakni aitem nomor 8 dengan pernyataan "Saya merasa hidup saya tidak adil".

Program terapi SEFT untuk menurunkan agresifitas remaja dari warga binaan LPKA TK.I Blitar diberikan dengan panduan modul yang telah disusun oleh peneliti agar program berjalan efektif dan efisien. Adapun jalannya penelitian atau Prosedur eksperimen dilakukan selama 2 sesi dengan rincian sebagai berikut

\section{Pertemuan I}

Sesuai kesepakatan antara peneliti dengan petugas LPKA TK I Blitar maka pertemuan pertama dilakukan pada tanggal 18 Juli 20182018 di aula pertemuan. Jumlah peserta berjumlah 16 orang. Proses yang terjadi selama pelatihan antara lain:a.) Pembukaan. Fasilitator mengucapkan salam, selamat datang dan mengucapkan terima kasih atas kehadiran peserta, Fasilitator juga mengenalkan peneliti dan anggota tim terapis SEFT juga memberikan kesempatan 16 orang peserta untuk mengenalkan dirinya secara bergiliran; serta fasilitator memberikan garis besar program SEFT yang akan diikuti selama dua hari berturut turut tersebut; b) Ice Breaking . Pemberian games interaktif seperti pulau beracun dan pemberian tantangan permainan lainnya dengan konsekuensi yang sifatnya menghibur yakni menampilkan hobi yang dimiliki kepada seluruh peserta terapi seperti menyanyi dan memainkan alat musik serta menyanyikan secara bersama-sama. Pada proses ini fasilitator bersama tim berbaur bersama-sama dengan peserta sehingga seolah olah tidak ada jarak antara tim fasilitator dan peserta. c.) Orientasi Pelatihan. Fasilitator meminta peserta untuk mengungkapkan tujuan dan persepsi peserta tehadap acara pelatihan pada gambar jenis buah-buahan yang telah dibagikan kepada masing-masing peserta dan selanjutnya ditempelkan pada pohon harapan. Adapun harapan peserta tehadap hasil penelitian antara lain kemampuan dalam mengendalikan amarah, memperoleh pengetahuan mengenai emosi dan menjadi pribadi yang lebih baik. Pada fase ini juga harapan didiskusikan dalam kelompok kecil secara mendalam dengan rasio 1 orang terapis dengan 3 orang peserta. Pada kesempatan ini ada sesi curhat sehingga memungkinkan rapport dibangun. d.) Kontrak pelatihan. Kontrak 
pelatihan ditujukan agar pelatihan berlangsung dengan kondusif terutama komitmen peserta untuk bersedia datang tepat waktu dan terlibat secara aktif dan partisipatif selama proses pelatihan atau terapi berlangsung. e.) Pengukuran awal atau pre-test sebelum terapi. Ketika rapport dan komitmen telah terbentuk, proses berlanjut dengan pemberian instruksi pengukuran awal atau pre test terhadap kondisi agresifitas 16 subjek.

\section{Pertemuan II}

Pada pertemuan kedua, fasilitator memberikan materi mengenai dasar-dasar SEFT misalnya sejarah, pengertian dan bagaimana SEFT dapat menjadi terapi yang efektif dan efisien serta bagaimana tahapantahapan dalam SEFT. Setelah materi diberikan, seluruh subjek diarahkan untuk memvisualisasi kejadian yang membuat mereka sangat marah di masa lalu dan berpotensi dalam menimbulkan perilaku agresif untuk selanjutnya dilakukan relaksasi. Selanjutnya ketua fasilitator menginstruksikan kepada seluruh anggota terapis atau co-fasilitator yang berjumlah 6 untuk memberikan terapi SEFT kepada keseluruhan subjek dengan pembagian satu terapis menangani 3 subjek. Proses ini membutuhkan waktu sekitar 5 menit untuk masing-masing subjek. Proses pemberian terapi SEFT menggunakan versi singkat (short-cut) yang meliputi : a) the set -up (menetralisir energi negatif yang ada di tubuh). Pada tahapan ini setiap peserta yang akan diterapi diminta untuk mengingat kejadian yang membuat dirinya marah dan dampaknya dirsakan pada saat ini sambil menekan dada tepatnya di bagian sore spot (titik nyeri) atau bagian dada atas yang akan menimbulkan rasa sakit jika ditekan. Pada saat yang bersamaan, subjek diarahkan untuk melakukan penentangna terhadap keyakinan bawah sadar negatif spontan atau perlawanan psikologis ( Psychological reversal) seperti " saya sedang marah karena teman-teman membicarakan hal buruk tentang diriku" dengan kalimat baru yagn diucapkan secara khusyuk seperti " $Y a$ Allah (Ya Tuhan kami), meskipun saya sedang marah karena teman-teman membicarakan hal buruk tentang diriku, saya ikhlas dan pasrah" sebanyak 3 kali. b). The Tune In. Fase ini merupakan fase lanjutan, terapis membantu subjek dengan masalah emosi agresif dengan memikirkan kejadian spesifik tertentu yang membangkitkan kemarahan yang ingin subjek ingin hilangkan. Ketika terjadi reaksi marah, subjek diminta untuk mengucapkan “ Ya Allah saya Ikhlas dan saya Pasrah “ bersamaan dengan langkah ini, dilakukan proses selanjutnya yaitu tapping, mengetuk ringan pada titik-titik kunci meridian. c.) The Tapping. Tapping merupakan prosedur ketukan ringan secara berulang dengan menggunakan dua ujung jari pada titik titik kunci dari the major energy meridians. Pada fase ini, fasilitator melakukan tapping pada titik-titik kunci versi singkat yakni 9 titik diantaranya Crown (titik di bagian atas kepala), eye brow (Titik permulaan alis mata), Side of eye (di atas tulang disamping mata), Under eye (2 cm kelopak mata), Under nose (titik di bawah hidung), Chin (diantara dagu dan bagian bawah bibir), Collar Bone (diujung tepat bertemunya tulang dada dan tulang rusuk pertama), Under arm (dibawah ketiak sejajar dengan dada), dan below nipple (2,5 $\mathrm{cm}$ di bawah dada).Setelah seluruh proses selesai, peserta diminta untuk menarik nafas panjang dan dalam dan menghembuskannya seolah-olah energi negatif ikut keluar sambil mengucapkan syukur atau alhamdulillah. Proses ini terkadang berlangsung beberapa kali atas permintaan peserta, dan dilakukan sendiri oleh peserta terutama terhadap kejadian spesifik yang melandasi munculnya perilaku agresif pada saat ini. 
Setelah semua proses terapi SEFT selesai dilaksanakan, fasilitator dan para terapis mengakhiri dengan proses evaluasi dan refleksi diri dengan durasi sesuai dengan kebutuhan subjek. Proses refleksi diri banyak memakan waktu karena subjek mulai belajar untuk mengidentifikasi kejadian negatif yang menjadi dasar munculnya emosi negatif dan memicu munculnya perilaku agresif pada dirinya. Ketika dirasa cukup, Peneliti kemudian mengambil alih kegiatan dengan memberikan isntruksi adanya post test. Post test dilakukan pada 16 subjek yang sama. Prosespengisian alat tes ini berlangsung selama 20 menit dengan meminta subjek mengisi berdasarkan yang dirasakan sekarang dan saat ini. Melalui proses ini dapat diketahui data agresifitas menggunakan sakala agresifitas yang sama pada masing-masing subjek paska pemberian intervensi.

Analisis data yang digunakan dalam penelitian ini menggunakan uji paired sample t-test dengan menggunakan program SPSS versi 23.0 for windows. Sebelum dilakukan uji paired sample $t$ test, dilakukan uji normalitas data dengan kolmogorov-smirnov dan homogenitas dengan lavene test.

\section{HASIL}

Data hasil penelitian diuji normalitasnya menggunakan kolmogorovsmirnov dan didapatkan hasil sesuai dengan tabel 1.
Tabel 1. Uji Normalitas KolmogorovSmirnov

\begin{tabular}{lc}
\hline \multicolumn{1}{c}{ Keterangan } & Nilai Signifikasi \\
\hline $\begin{array}{l}\text { Agresifitas sebelum } \\
\text { diberi terapi SEFT }\end{array}$ & 0,200 \\
$\begin{array}{l}\text { Agresifitas sesudah } \\
\text { diberi terapi SEFT }\end{array}$ & 0,200 \\
\hline
\end{tabular}

Berdasarkan data dari tabel 1 didapatkan hasil bahwa nilai signifikasi agresifitas sebelum diberi terapi SEFT dan sesudah diberi terapi SEFT sama-sama 0,200 ( nilai signifikasi $>0,05$ ) sehingga data terdistribusi normal. Data hasil penelitian tersebut diuji homogenitasnya sebelum dilakukan uji paired sample t-test. Uji homogenitas dapat dilihat pada tabel 2.

Tabel 2. Uji Homogenitas levene's

\begin{tabular}{cc}
\hline Levene Statistic & Sig \\
\hline .026 & .872 \\
\hline
\end{tabular}

Tabel 2 menunjukkan nilai levene's ditunjukkan pada baris nilai based on mean, yaitu 0, 026 dengan $p$ value (sig) sebesar 0, 872 di mana $>0,05$ maka berarti terdapat kesamaan varians antar kelompok atau yang berarti adanya homogenitas.

Data hasil kemudian diuji menggunakan uji paired sample t-test. Hasil analisis data dapat dilihat pada table 3. 
Tabel 3. Uji Paired Sample T-Test

\begin{tabular}{ccccc}
\hline & N & Sig. & Correlation & Mean \\
\hline $\begin{array}{c}\text { Agresifitas sebelum diberi terapi SEFT / } \\
\text { Pretest }\end{array}$ & & & 64,12 \\
& 16 & 0,030 & 0.168 & \\
$\begin{array}{c}\text { Agresifitas sesudah diberi terapi SEFT / } \\
\text { Posttest }\end{array}$ & & & 57,69 \\
& & & \\
\hline
\end{tabular}

Berdasarkan tabel 3 didapatkan bahwa nilai signifikansi adalah sebesar 0,030 (nilai signifikansi 0, $030<0,05$ ) sehingga dapat disimpulkan bahwa Ho ditolak, artinya terapi Spiritual Emotional Freedom Technique (SEFT ) berpengaruh terhadap penurunan agresifitas Remaja warga binaan Lembaga Pembinaan Khusus Anak (LPKA) Kelas I Blitar.

Hasil uji menunjukkan bahwa korelasi antara dua variabel adalah sebesar 0 , 168. Hal ini menunjukkan bahwa korelasi antara sebelum dan sesudah diberikan tritmen berhubungan secara nyata atau adanya korelasi positif yang lemah.

Pada output ketiga menunjukkan rata-rata (mean) sebelum diberi tritmen 64 , 12 dan sesudah diberi tritmen 57, 69. Dengan demikian nilai rata-rata agresifitas setelah diberikan SEFT lebih rendah dibandingkan dengan sebelum diberikan terapi SEFT.

\section{PEMBAHASAN}

Berdasarkan pada hasil uji beda dua berpasangan didapatkan nilai asymp. Sig (2-tailed) sebesar 0, 030. Karena nilai signifikansi $0,030<0,05$ sesuai dengan dasar pengambilan keputusan dalam paired sample t-test, maka dapat disimpulkan bahwa ada perbedaan yang signifikan pada pengisian kuesioner agresifitas skala agresifitas Buss \& Perry pada pengisian sebelum dan setelah pemberian perlakuan. Dari hasil uji beda juga dapat disimpulkan bahwa terapi Spiritual Emotional Freedom Technique (SEFT ) berpengaruh terhadap penurunan agresifitas Remaja warga binaan Lembaga Pembinaan Khusus Anak (LPKA) Kelas I Blitar.

Meninjau dari data penurunan agresifitas dialami oleh para subjek penelitian serta pendekanya jarak antara proses pemberian terapi dan pengukuran post test,menunjukkan bahwa perubahan yang diperoleh oleh remaja warga binaan Lembaga Pembinaan Khusus Anak (LPKA) Kelas I Blitar berlangsung dengan sangat cepat yakni hanya dalam waktu kurang dari sehari, yakni pemberian intervensi dilakukan bersamaan dengan pengukuran post test.

Penurunan agresifitas secara cepat menunjukkan beberapa hal pertama, hal penting yang menunjang percepatan efektifitas dari sebuah psikoterapi adalah adanya kepercayaan dari klien terhadap terapis. Dalam penelitian ini, proses membangun kepercayaan atau rapport, hubungan emosional yang cukup dengan klien dilakukan dengan melakukan ice breaking atau permainan dalam ruangan serta pentas seni pada hari sebelumnya, proses ini efektif dalam membangun keakraban sehingga para subjek dapat merasa nyaman dan selanjutnya bersikap 
kooperatif dengan serius mengikuti proses atau tahapan terapi, bahkan secara terbuka mampu mengungkapkan perasaan atau permasalahan yang belum terselesaikan unfinished business, yang menjadi pemicu munculnya perasaan atau emosi negatif termasuk perilaku agresif.

Proses pengenalan terhadap masalah yang tidak terselesaikan ini pada akhirnya mendorong subjek untuk melepaskan perasaan negatif dan mengikhlaskan perasaan tersebut sehingga berdampak pada penurunan agresifitas dalam waktu singkat. Pentingya peranan rapport sebagai langkah membangun komunikasi terapeutik sebagaimana yang dikemukakan oleh Capuzzi Gross (2011) bahwasanya hubungan rapport yang mendalam dan mengarah kepada hubungan terapeutik yang sifatnya membantu menjadi landasan yang efektif dalam sebuah terapi. Dalam proses terapis dalam penelitian ini dalam pemberian SEFT tidak hanya mengandalkan kemampuan terapisnya melainkan juga menjadi tempat yang nyaman bagi proses pelepasan energi atau emosi negatif di dalam diri klien.

Kedua, Proses pelepasan energi negatif pada diri subjek dalam terapi SEFT banyak mengadopsi langkahlangkah proses desensitisisasi sistematis terutama pada fase tune in, yakni proses dimana terapis mengajak subjek mengingat munculnya persitiwa-persitiwa spesifik terutama di masa lalu yang dapat membangkitkan emosi negatif. Pada fase ini ketika emosi kemarahan muncul sebagai akibat mengingat kejadian tidak menyenangkan, secara bersamaan subjek diajak melakukan afirmasi spiritual seperti " "Ya Allah..saya ikhlas..saya pasrah". Proses menghadirkan hal postifif terutama aspek spiritual secara kontinyu akan membuat subjek yang awalnya sangat sensitif atau emosional menjadi tidak sensitif lagi dan terbebas dari gangguan emosionalnya.

Penggunaan aspek spiritual seperti term Ikhlas dan Pasrah, dalam proses tune in tidak hanya menjadikan proses pelepasan energi negatif dimaknai sebagai proses katarsis semata, melainkan lebih pada proses pelepasan diri terhadap pemicu utama munculnya emosi negatif, sehingga menghasilkan dampak positif jangka panjang. Penggunaan aspek spiritual, tidak hanya bersifat ketundukan dan penyerahan masalah, melainkan juga memasukkan aspek pemaafaan tehadap peristiwa, diri sendiri maupun orang lain. Aspek Pemaafaan memberi dampak terapeutik yang luar biasa pada diri subjek, misalnya sebagian besar subjek menunjukkan perasaan lebih tenang dan nampak lega karena tidak harus dihantui perasaan merasa bersalah maupun melakukan rasionalisasi, yakni menyalahkan orang lain atas peristiwa atau kejadian tidak menyenangkan yang dialaminya. Bahkan pada diri beberapa subjek memunculkan perasaan optimistik terutama kesiapan mereka dalam menghadapi masa depannya, misalnya akan bekerja di perusahaan tertentu, sebagian ingin menekuni keahlian mereka di bidang otomotif, beberapa berrencan untuk melanjutkan pendidikan ke jenjang yang lebih tinggi.

Munculnya pikiran, perasaan yang lebih positif dan optimistik pada diri subjek tenang, dan lega setelah fase tune in atau SEFT secara keseluruhan, sesuai dengan penelitian Mary Baure bahwa proses terapi pemaafan yang diikuti subjek tidak hanya berhenti dengan memulihkan trauma dan melepas pengalaman sakit, melainan juga belajar mentransformasikan proses kognisi, afeksi, perilaku dan motivasi negatif ke dalam karya-karya 
kreatif, untuk menolong banyak orang (Ransley and Spy., 2005). Selain itu, ketika membiarkan pengalaman buruknya berlalu, subjek menjadi lebih kreatif dan berjuang mempertahankannya, dalam proses ini, individu mengubah kesedihan dan penyesalan, cara hidup yang negatif (represif ataupun agresif) serta pelaku dan hal-hal terkait dengan cara yang baru (Griswold, 2007).Di titik inilah, tune in tidak lain merupakan suatu konstruksi yang mengarah pada pelepasan sakit hati, serta pemulihan emosi dan pembaharuan relasi.

Ketiga, kekuatan tapping dalam SEFT yang mampu memotong mata rantai atau " short cut" aliran atau sistem energi tubuh yang terganggu dengan tepat, memungkinkan daya efektifitas terapi ini langsung dirasakan oleh beberapa orang subjek. Hal ini dimungkinkan karena titiktitik yang ditapping merupakan titik-titik kunci the major energy meridians, yang jika diketuk beberapa kali akan berdampak pada ternetralisasirnya gangguan emosi atau rasa sakit yang dirasakan, karena aliran energi tubuh berjalan dengan normal dan seimbang kembali. Dalam keseluruhan proses tapping diarahkan pada penyelarasan kembali sistem energi tubuh (Zainuddin, 2010).

Di samping tiga hal diatas, proses evaluasi diri atau sharing pengalaman terhadap perubahan diri subjek penelitian pasca mendapatkan tritmen (perlakuan) merupakan aspek penting yang berkontribusi dalam menguatkan dampak penurunan agresifitas yang dirasakan subjek. Pada fase ini, subjek akan mengenali tentang perubahan yang terjadi, dan menjadi lebih percaya diri serta mandiri untuk mengelola dan mengatasi perilaku agresif yang dimilikinya. Dengan demikian, secara keseluruhan terapi SEFT sebagai terapi yang mengkombinasikan antara spiritualitas (melalui doa, keikhlasan dan kepasrahan) dan energy psychology (dengan cara menyeimbangkan kembali energi tubuh) cukup efektif untuk menurunkan agresifitas pada Remaja warga binaan LPKA Kelas I Blitar.

\section{KESIMPULAN}

Hasil Penelitian ini menunjukkan bahwa terapi Spiritual Emotional Freedom Technique (SEFT) efektif dalam menurunkan agresifitas Remaja warga binaan Lembaga Pembinaan Khusus Anak (LPKA) Kelas I Blitar. Efektifitas hasil terapi SEFT yang cepat dalam penelitian ini disebabkan karena beberapa faktor diantaranya karakteristik SEFT khususnya versi short cut yang sederhana dan mudah diaplikasikan, penggunaan multi teknik psikologi seperti psikoanalisis (unfinished business), desensitisasi sistematis, serta spiritual, juga mengarah pada pentingnya peranan terapis dalam membangun rapport dan hubungan terapeutik selama proses terapi. Kelemahan utama dalam penelitian ini adalah tidak adanya kelompok pembanding, oleh karena itu dalam eksperimen lanjutan dapat ditambahkan kelompok kontrol yang dapat diberikan placebo atau sebagai waiting list. Dengan demikian ada tidaknya pengaruh pemberian terapi akan lebih nampak, peneliti dapat membandingkan hasil paska tes antara kelompok yang diberikan terapi (kelompok eksperimen) dan kelompok yang tidak diberikan terapi (kelompok kontrol). Penelitian ini memungkinan diintegrasikannya terapi SEFT sebagai model terapi yang telah teruji efektif secara ilmiah pada lembaga pemasyarakatan anak di Indonesia baik yang dilakukan oleh terapis khusus atau 
para pamong atau petugas pendamping (lapas).

\section{DAFTAR PUSTAKA}

Baron, R. A., \& Byrne, D. (2005). Psikologi Sosial (terj. Djuwita,R). Jakarta : Erlangga

Bisnis, (2016). Catatan Akhir Tahun KPAI : Anak Sebagai Pelaku Kejahatan Meningkat [WWW Document]. URL Diunduh dari http://www.lifestyle.bisnis.com Pada februari 2018.

Buss, H. Arnold \& Perry, Mark. (1992). The Aggression Questionnaire. Journal of Personality and Social Psychology, 63 (3), 452-459.

Capuzzi, D., \& Gross, D.R. (2011). Counseling and Psychotherapy: Theories and Interventions (5th edition). Alexandria: ACA.

Griswold, C.L.( 2007). Forgiveness: A Philosophical Exploration. New York: Cambridge University Press.

Haney,C. (2003) . Prisoners Once Removed: The Impact of Incarceration and Reentry on Children, Families, and Communities. Washington DC : Urban Institute Press

Hukum Online, Undang-Undang No 11 tahun 2012 tentang sistem peradilan pidana anak. http://www. Hukum Online com. Diakses 2 Juli, 2019

Hurlock.( 2003). Psikologi Perkembangan. Jakarta: Erlangga.

Kartono, K. (2014). Patologi Sosial 2: Kenakalan Remaja. Jakarta: PT Raja Grafindo Persada.
Kepala LPKA, K.L.( 2017). "LPKA Kelas I Blitar." Hasil wawancara pribadi: 27 Agustus 2017

Kompas, 27 September 2010, “ kekerasan Terhadap Anak"

KPAI, Undang-undang Republik Indonesia No.3 Tahun 1997 tentang pengadilan anak.

http://www.kpai.go.id/hukum/undan g-undang-uu-ri-no-3-tahun-1997tentang-pengadilan-anak. Diakses pada 14 Agustus 2019

Monks, F.J., Knoers, A.M.P., Haditono, S.R. (2006). Psikologi Perkembangan Pengantar dalam Berbagai bagiannya. Yogyakarta : Gadjah Mada University Press/

NN, 2017. "Program LPKA." Hasil wawancara pribadi: 27 Agustus 2017

Ransley, C. \& Spy ., C., (2005). Forgiveness and the Healing Process: A Central Therapeutic Concern. New York: BrunnerRoutledge.

Redaksi Sinar Grafika. (2002). UndangUndang perlindungan anak :UU No. 22 Tahun 2002, Jakarta : Sinar Grafika.

Sakdullah, M., 2013. Pengaruh Terapi SEFT (Spiritual Emotional Freedom Technique) Dalam Menurunkan Agresifitas Siswa MA Darul Ulum Ngaliyan- Semarang. Skripsi tidak dipublikasikan Semarang. IAIN Walisongo. 
Sears, D. O .(2001). Psikologi Sosial Jilid

2 . Jakarta: Erlangga.

Wallin, K. \& Durr, M. (2002). Creativity and expressive art in social emotional learning. Journal of Reclaiming Children and Youth, 11 (1), 30 .

Zainuddin, A.F., 2010. Spiritual Emotional Freedom Technique SEFT For Healing, Success, Happiness And Greatness. Afzan Publishing, Jakarta. 